\title{
Wire-line log-based stratigraphy of flood basalts from the Lopra-1/1 A well, Faroe Islands
}

\author{
Lars O. Boldreel
}

The present study shows that it is possible to use conventional borehole logs to perform a detailed lithological/stratigraphical division of a column of subaerially extruded basalt. A stratigraphical division of the subaerial flood basalts penetrated by the Lopra-1/1A well has been carried out using new wire-line logging data measured in 1996 in the interval 200-2489 m depth. Resistivity data acquired in the interval 200-2178 m depth during 1981 after the initial drilling of the Lopra-1 well have also been incorporated. Eighty-six individual flow units, 18 compound flows and two dolerite dykes have been identified by combining the NPHI porosity, RHOB density, P-, S- and Stonely-sonic transit time, calliper and resistivity logs. Fifty-two sedimentary/tuffaceous layers have also been identified using the CGR and SGR gamma ray and potassium logs in combination with the aforementioned logs. Within the flow units, sonic velocity, density and resistivity are highest in the core where porosity is lowest. This relation is reversed in the uppermost and basal zones of the flow units. The sonic velocity in the core seems to be independent of the thickness of the flow unit. Porous zones seem abundant in some cores and the total section of cores containing porous zones constitutes more than $70 \%$ of the thickness of its flow unit, but where porous zones are absent the core makes up only roughly $50 \%$ of the thickness of the flow. It is suggested that the flow units with porous cores represent aa flows ( $88 \%$ of the flow units) and the others pahoehoe flows ( $12 \%$ of the flow units).

The log pattern of the flow units (crust, core and basal zone) is similar to log patterns reported from other basalt plateaux. However the patterns in Lopra-1/1A show a larger variation than elsewhere, suggesting that the flow units are more complex vertically than previously thought. Statistical analysis of P-, S- and Stonely-waves, RHOB, NPHI, resistivity, gamma and calliper logs has been carried out. Cross-plots based on the lithological divisions have been produced that show a pronounced reduction in scattering versus P-sonic transit time and P- and S-sonic, RHOB and NPHI logs correlate with depth. The geochemical logs do not reflect the cyclic structure of the flow units and probably represent the primary composition of the basalt. The thorium log especially indicates flow units with high and low radioactivity and it is suggested that a minimum of 36 flow fields form the logged part of the lower basalt series. Dolerite units described in previous works have been confirmed based on the combined interpretation of wire-line logs. The log data suggest that the subaerially extruded basalt has its base at a depth of approximately $2490 \mathrm{~m}$ and that a hyaloclastite succession is found below that depth. The transition from subaerially extruded basalt to hyaloclastite produces a negative acoustic impedance and it is found that the transition corresponds to a negative reflection interpreted on VSP surveys from 1988 and 1994.

Keywords: Flood basalts, flood basalt petrophysics, North Atlantic, Faroe Islands, Lopra-1/1A well, Faroese basalt lithology, wire-line logs

Geological Institute, University of Copenhagen, Øster Voldgade 10, DK-1350 Copenhagen K, Denmark.

E-mail: lob@geol.ku.dk 
The Lopra-1 well was deepened in 1996 to drill through a pronounced negative seismic reflection at an estimated depth of $2366 \mathrm{~m}$ and an additional reflection at a depth of $3486 \mathrm{~m}$ found from the analysis of the data acquired in Vertical Seismic Profiling (VSP) surveys carried out in 1988 (Kiørboe \& Petersen 1995) and 1994. Several wireline logs were run in the upper part of the well (0-2184 m) that had been drilled in 1981 to supplement the previous logging (Nielsen et al. 1984). A more extensive logging programme was carried out in the deepened part of Lopra$1 / 1 \mathrm{~A}$ and the new wire-line data for the entire well have been analysed.

The wire-line logs were used to investigate the lower basalt series of the Faroe Islands, to construct a lithological and stratigraphical division of the lava sequence and to test whether a subdivision of the basalt column would result in better statistics of its physical properties. The results of the new logging have been both new understanding and results in greater detail than was possible from the data available from the 1981 drilling and logging, and they supplement studies carried out in other basalt covered regions in the world.

It was intended that analysis of the wire-line logs acquired in 1996 should include the logs acquired in 1981, but this turned out to be complicated. It was possible to use the older resistivity data only after they had been corrected manually within individual flow units. Consequently this paper is concerned mainly with interpretation of the wire-line log data measured in 1996 in the subaerially extruded lower basalt series.

\section{Geology of the Faroe Islands}

The Faroe Islands consist of subaerially extruded tholeiitic basalt flows erupted in the late Paleocene in connection with the opening of the northern North Atlantic Ocean. The basalts consist of three lava formations called the upper, middle and lower basalt formations (or series). A tuff-agglomerate zone and a coal-bearing horizon separate the lower and the middle formations (e.g. Rasmussen \& Noe-Nygaard 1969, 1970; 1990). The three lava formations are all exposed on the islands and the lowest exposed stratigraphical level is found in the southern part of the southernmost island, Suðuroy, where the original Lopra-1 well was drilled. Geological and geophysical investigations based on data from the Lopra-1 well resulted in six papers published in Berthelsen et al. (1984). The geology of the well was described by Hald \& Waagstein (1984) who found the lava to consist of tholeiitic basalt. A stratigraphical division of the well was established on the basis of drill cuttings collected every $2 \mathrm{~m}$, five cores, the wireline logs (acquired in 1981) and geochemical rock analysis. This resulted in a division of the sequence into 87 flow units, 27 sedimentary units and two dolerite dykes within the interval 200-2180 m depth plus an additional 10 flow units and five sedimentary beds in the cased interval 0-200 m. The bedding in the well was established using chilled vesicular (amygdaloidal) basalt as a marker of flow tops. The observed transition between vesicular and non-vesicular basalt was afterwards correlated to the neutron-neutron and resistivity logs (Waagstein et al. 1982; Nielsen et al. 1984). The flow units range in thickness from a few metres to about $50 \mathrm{~m}$ with the majority of flows having thicknesses of 5-10 $\mathrm{m}$ or 10-15 m. Most of the flows were interpreted as aa type based on the characteristics of the topmost cuttings. Sediments were observed on the top of about one third of the drilled lava flows. Two dolerite dykes were found at 834-738 $\mathrm{m}$ and 616$508 \mathrm{~m}$, and Hald \& Waagstein (1984) suggested that the real thickness of both dykes is about $9 \mathrm{~m}$ assuming an inclination of $85^{\circ}$. The volcaniclastic sediments were distributed more or less randomly throughout the drilled sequence, and no correlation was found either with flow thickness or with chemical composition of the flows. It was concluded that there were no major hiatuses during eruption of the drilled sequence or the overlying $700 \mathrm{~m}$ of exposed lower basalt formation.

\section{Data from the Lopra-1 well}

The original Lopra-1 stratigraphic well reached a total depth (TD) of $2184 \mathrm{~m}$ in 1981. It was deepened in 1996

Table 1. Wire-line log suites 1,2 and 5 used in this study

Suite 1: 196-2184 m

(in the existing hole drilled in 1981).

Two log runs were carried out:

Run No. 1: LDL-CNL-NGS (recording a maximum hole deviation of $1^{\circ}$ from the vertical). GR was run to the surface

Run No. 2 pass 1:DSI-Cross and U\&L Dipole

Run No. 2 pass 2: DSI-P\&S and Stoneley.

Suite 2: $2185-3158 \mathrm{~m}$

Three runs were carried out:

Run No. 1: LDL-CNL-NGS-DSI.

Run No. 2: SHDT-GR-AMS

recording a maximum hole deviation from the vertical of $14^{\circ}$

Run No. 3: GHMT-GR.

Suite 5: 2204-3531 m

Run No 1: MSCT-GR 
to a TD of $3158 \mathrm{~m}$ and was sidetracked from $3091 \mathrm{~m}$ after a partly unsuccessful fishing operation. The sidetrack (Lopra-1A) well reached TD at 3565 m and the Lopra-1/1A well sections were plugged and abandoned after final wire-line logging. The Lopra-1/1A well has been logged on various occasions. Caliper, gamma ray, resistivity, neutron-neutron porosity and sonic logs were acquired in 1981 (Nielsen etal. 1984), but the sonic log and part of the resistivity log turned out to be unsuccessful (Nielsen et al. 1984). Successful VSP surveys were carried out in 1988 (Kiørboe \& Pedersen 1995) and 1994, and ahead-of-tool predictions were carried out in order to evaluate the remaining thickness of the basalt. The deepened well was logged in 1996 and a large number of logs, including a VSP, were obtained. A total of five suites were run between 196 and $3565 \mathrm{~m}$ depth. Suites 1 to 5 were acquired in the intervals 196-2184 m, 2185-3158 m, 3091-3516 m, 3516-3561 $\mathrm{m}$ and 2204-3531 m, respectively. Three of the suites have been used in this study, suites 1, 2 and 5 (Table 1).

From the suite of wire-line logs, the calliper, SGR (total gamma ray), CGR gamma ray (computed gamma ray, including measurements of thorium and potassium), P-, S- and Stonely-wave transit time, RHOB (bulk density), NPHI (neutron porosity hydrogen index), resistivity (short and long from 1981), potassium, thorium and uranium logs were selected for this study. After processing (apart from the resistivity logs) by Schlumberger, the data were interpreted on an SGI UNIX workstation using Landmark software (Stratworks ${ }^{\circledR}$ and Petroworks ${ }^{\circledR}$ ). There were problems with the logs acquired by the spectral gamma log tool in the deepened part of the Lopra-1 well, probably because calibration had not been carried out properly. The data were corrected by shifting the thorium, potassium and CGR logs to the responses measured in the previously drilled hole. An attempt was made to correlate the wireline logs from 1981 and 1996, as both suites include a calliper. That task proved not to be simple, probably because of different cable tensions and depth annotations. It is felt that the 1981 resistivity data have been correctly adjusted by manual editing and adjusting the 1981 data to the interpretation of the wire-line suite obtained in 1996.

\section{Characteristics of subaerially extruded basalt}

It is known from various workers (e.g. Cashman \& Kauahikaua 1997; Self et al. 1997; Thordarson \& Self 1998; Waagstein 1999) that subaerially extruded lava flows have some characteristics in common and the following discussion focuses on those characteristics which may be ex- pected to be confirmed from the logging suite run in the Lopra-1 well. A lava formed in a single volcanic eruption is called a flow field and consists of one or several lava flows erupted more or less continuously from the same vent area or fissure. The commonest diagnostic criterion likely to be used is the chemical composition of the basalt magma that is assumed to be fairly constant during an eruption.

A lava flow may consist of several flow units, partly or completely surrounded by chilled crust. A flow unit consists of a lava crust, a lava core and a basal zone. The appearance of the crust has been used to define two morphological types, aa and pahoehoe, in both of which the crust is usually much thicker than the basal zone. The core typically consists of massive basalt with few or no vesicles, and sometimes displays flow banding. Thick cores often show a more or less columnar jointing in the lower part which propagated upwards perpendicular to the base of the flow during cooling. Thinner and less regular columns in the upper part may have propagated downwards from the top of the flow. Vesicular zones in the core have been reported by McMillan et al. (1987) who showed a two-stage vesiculation of basalt from the Colombia River Basalt Plateau. Walker (1989) studied vesicle distribution in profiles across flow units, on Hawaii primarily of pahoehoe type but also of aa type, and concluded that the distribution of vesicles does not need to be symmetrical about a horizontal median plane.

The rubble near the surface of a flow unit in aa lava may be unconsolidated with fractures and voids filled by tuff, and sometimes the rubble fragments are welded. The fragmentation decreases downwards, and a complete gradation into unbrecciated basalt in the core of the flow unit is commonly seen. Thick flow units in the lower formation on the Faroes are typically from several metres to several tens of metres thick, as seen on Suðuroy (Waagstein 1999). Thick flow units usually have an upper rubbly crust several metres thick whereas the lower crust or basal zone is generally less than one metre. The vesicles and fractures are usually filled with secondary minerals. Aa lavas on Hawaii normally consist of a large number of thin flow units, $0.2-2.0 \mathrm{~m}$ thick.

Pahoehoe type lava has a continuous vesicular crust that is distinguished from its core mainly by its vesicularity, and roughly half of the total thickness of a pahoehoe flow consists of crust. The crust is highly vesicular near its top surface with abundant small vesicles that often exceed 50\% of the bulk rock volume. The vesicles show an overall decrease in abundance and increase in size downwards reflecting the increase in gas pressure exerted by the thickening lava crust. The vesicles are often arranged in hori- 
Table 2. Physical properties of basalt based on wire-line logs

\begin{tabular}{|c|c|c|c|c|c|c|c|}
\hline & $\begin{array}{c}\text { Kern \& Richter } \\
\quad(1979) \\
\text { Faroese basalt }\end{array}$ & $\begin{array}{c}\text { Berlitz et al. } \\
\quad(1988) \\
\text { Chile Japan }\end{array}$ & $\begin{array}{c}\text { Goldberg et al. } \\
(1994) \\
\text { USA }\end{array}$ & $\begin{array}{c}\text { Planke } \\
(1994) \\
\text { ODP Hole 642E }\end{array}$ & $\begin{array}{c}\text { Christensen } \\
(1996)\end{array}$ & $\begin{array}{c}\text { Planke \& Flovenz } \\
(1996) \\
\text { ODP Hole } 917\end{array}$ & $\begin{array}{c}\text { Singh } \\
(1996) \\
\text { Deccan traps }\end{array}$ \\
\hline$V_{p}(\mathrm{~km} / \mathrm{sec})$ & $4.79-6.21$ & & $6.2^{\S}$ & & $5.91^{\S}$ & $3-5.54^{\S}$ & \\
\hline$V_{p}$ massive $(\mathrm{km} / \mathrm{sec})$ & & & & $5.0-6.0$ & & & \\
\hline Vp sediments $(\mathrm{km} / \mathrm{sec})$ & & & & $3.0-5.3$ & & & \\
\hline Vs $(\mathrm{km} / \mathrm{sec})$ & $2.73-3.52$ & & & & $3.03^{\S}$ & & \\
\hline Porosity & & 10 p.u. & $10 \% \#$ & & & & \\
\hline Porosity massive & & & & $<5 \%$ corrected & & & \\
\hline Porosity porous & & & & $15-30 \%$ corrected & & & \\
\hline Porosity sediment & & & & $10-20 \%$ corrected & & & \\
\hline Density $\left(\mathrm{g} / \mathrm{cm}^{3}\right)$ & $2.73-3.52$ & $3.06 * ; 2.8^{\dagger}$ & $3.05^{\S}$ & $2.3-2.8$ & $2.882^{\S}$ & $2.5^{\S}$ & \\
\hline Gamma-ray (GAPI) & & 15 & $75 \pm 25$ & & & & \\
\hline Gamma-ray (mas) & & & & 5 GAPI & & & $15-40$ cps \\
\hline Gamma-ray (por) & & & & & & & $40-100$ cps \\
\hline Gamma-ray (sed) & & & & 20 GAPI & & & $100-300 \mathrm{cps}$ \\
\hline Unit thickness $6-8 \mathrm{~m}$ & & & & & & $6-8 \mathrm{~m}$ & \\
\hline
\end{tabular}

* Chile; ${ }^{\dagger}$ Japan; ${ }^{\#}$ uncorrected values; ${ }^{\S}$ average

cps: counts per second; p.u.: neutron porosity units; GAPI: Gamma log in API units;

mas: The massive core of a flow unit; por: The porous crust of a flow unit; sed: sediments between flow units.

zontal layers with a vertical spacing of about $10 \mathrm{~cm}$, especially in the upper part of the crust. Horizontal vesicular veins or sheets of basalt up to about $10 \mathrm{~cm}$ thick may occur near the top of the core, but otherwise the core of the flow is usually massive with no or only a few relatively large vesicles. The basal vesicular zone is usually a few tens of centimetres thick at most and sometimes sub-vertical pipes are found within it.

\section{Sediments}

Thin beds of tuff with a vertical extent of between a few centimetres and few tens of metres are found within the Faroes lava succession. The beds are typically very finegrained, clayey, fissile with vivid colours. The tuff beds are buried soils (palaeosols) formed by disintegration and chemical break down of volcanic materials. The beds may originate from either airfall volcanic ash or from in situ weathering of the lava flows (Hald \& Waagstein 1984; Waagstein 1999). Microfossils suggest that the latter formed slowly enough to allow immigration of plants and other living organisms before being covered by the next lava flow, thus representing quiescence in the erupting environment (Lund 1983).

\section{Previous work on the relationship between lithology and logging response}

The geophysical response of interbedded sediment/tuff layers and subaerially extruded basalt, characterised both by the rhythmic succession of flow units and the subdivision of the flow unit into three parts, may be examined from wire-line logging data and drilling penetration rate. This has been done by a number of authors from various places around the world: the Faroe Islands (Kern \& Richter 1979; Nielsen et al. 1984), ODP Hole 642 (Planke \& Flovenz 1996), ODP Hole 642E (Planke 1994), Newark Basin (Goldberg et al. 1994), North Sea basalt flows from the Middle Jurassic (Rider 1996), Deccan Trap area (Buckley \& Oliver 1990; Singh 1996), Japan and Chile (Berlitz et al. 1988) and a geothermal well with no cited geographical location (Sanyal et al. 1980). Physical parameters obtained from the analyses of wire-line data by these workers are presented in Table 2, and the results from the present study are found in Table 3. In two studies where the layered basalt flows represent the Seaward Dipping Reflector Sequence, from ODP Hole 917 (which also had formation microscanner images) (Planke \& Flovenz 1996) and from ODP Hole 642E (Planke 1994), the interpretation of wire-line logs was integrated with continuous coring.

The above studies suggest that the following features are of special interest in relation to the wire-line logs obtained from Lopra-1/1A.

The often vesicular, fractured and altered crust and flow tops are characterised by gradients in the values represented 
Table 3. Physical properties of basalt based on wire-line logs from Lopra-1

\begin{tabular}{|c|c|c|c|}
\hline & Average & Median & (Min-Max) \\
\hline$V_{p}$ flow unit & 5.53 & 5.78 & $(2.94-7.47) \mathrm{km} / \mathrm{sec}$ \\
\hline Vp core & 5.83 & 5.90 & (2.94-7.47) \\
\hline$V_{p}$ crust & 4.69 & 4.73 & $(2.94-6.63)$ \\
\hline$V_{p}$ compound flow & 4.92 & 5.02 & $(2.43-6.57)$ \\
\hline$V_{p}$ dolerite dyke & 6.08 & 6.29 & (3.37-7.58) \\
\hline Vp sediments & 4.26 & 4.30 & $(2.86-6.31)$ \\
\hline Vs flow unit & 2.97 & 3.11 & $(1.74-4.01) \mathrm{km} / \mathrm{sec}$ \\
\hline Vs core & 3.14 & 3.19 & $(2.00-4.01)$ \\
\hline Vs crust & 2.52 & 2.54 & $(1.74-3.82)$ \\
\hline Vs compound flow & 2.59 & 2.60 & $(1.82-3.44)$ \\
\hline Vs dolerite dyke & 3.28 & 3.39 & $(1.90-4.03)$ \\
\hline Vs sediments & 2.34 & 2.34 & $(1.90-3.34)$ \\
\hline Vst flow unit & 1.46 & 1.47 & $(1.11-1.52) \mathrm{km} / \mathrm{sec}$ \\
\hline Vst core & 1.47 & 1.48 & $(1.22-1.52)$ \\
\hline Vst crust & 1.42 & 1.43 & $(1.11-1.50)$ \\
\hline Vst compound flow & 1.44 & 1.44 & $(1.19-1.49)$ \\
\hline Vst dolerite dyke & 1.45 & 1.47 & $(1.28-1.48)$ \\
\hline Vst sediments & 1.40 & 1.41 & $(1.19-1.49)$ \\
\hline Porosity flow unit & 0.19 & 0.16 & $(0.04-0.50) \%$ Ispu* \\
\hline Porosity core & 0.15 & 0.14 & $(0.04-0.47)$ \\
\hline Porosity crust & 0.31 & 0.32 & $(0.11-0.50)$ \\
\hline Porosity compound flow & 0.30 & 0.30 & $(0.15-0.49)$ \\
\hline Porosity dolerite dyke & 0.12 & 0.10 & $(0.04-0.45)$ \\
\hline Porosity sediments & 0.31 & 0.32 & $(0.15-0.44)$ \\
\hline Density flow unit & 2.85 & 2.96 & $(1.55-3.15) \mathrm{g} / \mathrm{cm}^{3}$ \\
\hline Density core & 2.90 & 2.93 & $(1.57-3.15)$ \\
\hline Density crust & 2.66 & 2.66 & $(1.55-3.15)$ \\
\hline Density compound flow & 2.74 & 2.76 & $(2.03-3.01)$ \\
\hline Density dolerite dyke & 2.90 & 2.95 & $(1.51-3.04)$ \\
\hline Density sediments & 2.58 & 2.64 & $(2.53-2.95)$ \\
\hline Gamma ray flow unit & 10.40 & 9.50 & (0.7-61.1) API \\
\hline Gamma ray core & 10.23 & 9.39 & $(0.0-33.77)$ \\
\hline Gamma ray crust & 9.75 & 9.43 & $(0.0-33.76)$ \\
\hline Gamma ray compound flow & 10.32 & 9.18 & $(1.34-36.53)$ \\
\hline Gamma ray dolerite dyke & 4.74 & 4.57 & $(1.36-26.95)$ \\
\hline Gamma ray sediments & 27.09 & 25.21 & $(1.66-78.28)$ \\
\hline Calliper flow unit & 10.47 & 10.52 & (6.64-15.83) inches \\
\hline Calliper core & 10.15 & 10.26 & $(6.64-15.83)$ \\
\hline Calliper crust & 11.81 & 11.84 & $(8.24-15.62)$ \\
\hline Calliper compound flow & 11.96 & 11.96 & $(10.10-14.61)$ \\
\hline Calliper dolerite dyke & 11.73 & 11.80 & $(9.49-18.58)$ \\
\hline Calliper sediments & 12.12 & 12.08 & $(10.09-18.41)$ \\
\hline Resistivity (IId) flow unit & 558.39 & 473.36 & $(24.07-1777.40)$ om \\
\hline Resistivity (IId) core & 661.47 & 601.04 & (37.35-1777.40) \\
\hline Resistivity (IId) crust & 255.35 & 164.21 & $(24.67-1197.98)$ \\
\hline Resistivity (IId) compound flow & 283.45 & 187.91 & $(52.07-1135.72)$ \\
\hline Resistivity (IId) dolerite dyke & 1038.07 & 1055.64 & $(145.01-1773.44)$ \\
\hline Resistivity (IId) sediments & 178.05 & 144.09 & $(26.74-890.36)$ \\
\hline Resistivity (Ild) flow unit & 317.16 & 288.27 & $(18.52-766.66)$ om \\
\hline Resistivity (IIs) core & 369.51 & 356.15 & $(32.43-766.68)$ \\
\hline Resistivity (Ils) crust & 165.68 & 122.45 & $(18.52-731.21)$ \\
\hline Resistivity (Ils) compound flow & 167.66 & 121.70 & $(26.32-596.06)$ \\
\hline Resistivity (IIs) dolerite dyke & 515.80 & 527.20 & $(22.37-760.66)$ \\
\hline Resistivity (IIs) sediments & 91.91 & 76.63 & $(22.37-309.21)$ \\
\hline
\end{tabular}

* limestone porosity units; om: ohms $\mathrm{m}^{2} / \mathrm{m}$ 
by the porosity dependent wire-line logs. The P-wave velocity, density and resistivity values are rather low but increase into the flow, in contrast to the porosity log that shows rather high values that decrease into the flow (Planke \& Flovenz 1996). Natural gamma counts are intermediate (Goldberg et al. 1994; Planke 1994; Rider 1996; Singh 1996). The crust is often soft and weathered and can be recognised from an increase in the rate of drilling pentration (Buckley \& Oliver 1990).

The massive core is characterised by rather high values of P-wave velocity, density and resistivity in contrast to rather low values of porosity and low natural gamma counts (Goldberg et al. 1994; Planke 1994; Planke \& Flovenz 1996; Rider 1996; Singh 1996). A number of Faroes basalt samples, selected to be free of fractures and secondary alteration, showed in laboratory experiments that the P-and S-wave velocities increase as a function of pressure (Kern \& Richter 1979). Two distinct gamma ray count rates of primary potassium and thorium show that high-gamma basalts exist (Buckley \& Oliver 1990).

The basal zone is characterised by gradients in values from the wire-line logs representing porosity. P-wave velocity, density and resistivity decrease rapidly downwards whereas porosity increases downwards near the base of the unit (Goldberg et al. 1994; Planke 1994; Planke \& Flovenz 1996).

The sediments interbedding the flow units show very low resistivity and very high gamma counts (Nielsen et al. 1984; Singh 1996) and intermediate porosity and density values (Planke 1994).

Nielsen et al. (1984) showed that different series within a large vertical section of basalt flows could be identified primarily from the results of the natural gamma ray log. Sanyal et al. (1980) showed that lithology could be discriminated by analysing wire-line logs and making crossplots of especially the gamma-ray and neutron responses.

Some of the results are of special interest in the context of the present work on the Lopra-1 logs. A positive correlation between flow thickness and mean velocity simply reflects increased proportions of massive basalt in thicker flows (Planke 1994); velocity and density gradients at the top and bottom of a flow unit are largely independent of flow thickness (Planke \& Flovenz 1996); Goldberg et al. (1994) and Kern \& Richter (1979) found that travel time correlates directly with porosity and showed that it also decreases with depth in sediments. Planke (1994) found flows between 0.6 and $18.5 \mathrm{~m}$ thick while most sediment was less than $1 \mathrm{~m}$ thick. Radioactive gamma ray and potassium logs are asymmetrical, having high values at flow tops, decrease gradually towards a central wide minimum and increase rapidly again near the flow base.

\section{Principles of interpretation of the Lopra-1 well wire-line data}

It is assumed that the principles and observations about the wire-line interpretation of subaerial basalt successions discussed in the previous section can be applied to the interpretation of the wire-line logging suite carried out in the Lopra- 1 well. The physical properties of a basalt flow are related primarily to active mechanical processes (i.e. growth through inflation, cooling history, the environment into which the flow was extruded, stress, faulting and whether it is a pahoehoe or a flow type) and to secondary processes such as leaching and mineral growth. Thus it is expected that, within subaerially extruded flows, the responses of the sonic, porosity, density, resistivity and calliper logs, all of which record physical properties, will follow a generalised cyclic pattern. On the other hand the geochemical properties reflect a combination of magma composition, primary mineralogy, weathering, leaching of various elements and growth of secondary minerals so the response from the gamma (SGR and CGR), thorium, potassium and uranium wire-line logs, all of which represent geochemical properties, will not necessarily show similar cyclic patterns.

As a first approach, an idealised cross-section of a flow is envisaged as follows: a porous crust at the top of the flow grades into a massive core. A basal zone below the massive core appears abruptly and is located on top of the preceding tuff/sedimentary layer or, in case such a layer is absent, on top of the crust of the preceding flow.

The porous crust represents a transition zone between the tuff/sediment layer above it and the massive core beneath it. Its physical properties thus change gradually, represented by the readings of the physical logs changing gradually downwards from those observed at the very top of the flow or in the overlying tuff/sediment layer to the values of the underlying massive core. It is thus expected that values for the transit time of both the P- and S- waves, porosity and the diameter of the well will decrease downwards, whereas the density and resistivity will increase downwards. The interpretation of the geochemical logs is ambiguous because the crust could either be leached or enriched in elements compared to the original composition of the flow.

The massive core is often found to be characterised by uniform values of the sonic, porosity, density, resistivity and calliper logs. More specifically, the core is recognised by the low transit time (high velocity) of the P-, S- and Stonely-waves, low values of porosity, the well diameter and drilling rate, but high values of density and resistivity. The chemical logs are expected to show a concentration 
for the core and crust that more or less reflect the original chemical composition of the flow.

The thin basal zone is recognised physically as a sharp transition above the underlying lava flow/tuff horizon. An abrupt change downwards of the log patterns is expected. Values of transit time of P-, S- and Stonely-waves are expected to increase downwards (i.e. a downward fall in velocities) as are those of porosity and well diameter, but resistivity and density should decrease downwards.

Sediment deposited on top of a lava flow should appear on the petrophysical logs as follows: high values of transit times of P-, S- and Stonely-wave sonic logs (low velocity), high values of porosity, low values of density, resistivity, distinctly high values of the gamma ray, especially the spectral gamma ray responses (particularly for the compensated gamma ray and potassium curves) and enlarged diameter of the well.

\section{Lopra-1 results}

The wire-line-logs are shown on Enclosure 1. Individual curves are arranged such that their visual impression can be correlated easily with the inferred lithology. Inspection shows that while the basal zone of many flow units can be recognised, it is too thin to be treated statistically as has been done for the core, crust, compound flows, dolerite dykes and sediments. Analysis of the basal zone has therefore been included in that of the core.

\section{Calliper}

The calliper log shows that the diameter of the borehole varies cyclically in the range of 9-18" in the upper part of the hole that was drilled in 1981 with an 8.5" bit (Enclosure 1). The diameter is within the interval $6.5^{\prime \prime}$ to $13^{\prime \prime}$ in the deepened hole drilled with a $6.5^{\prime \prime}$ bit. The diameter tends to decrease with depth in the upper hole but it is close to being gauge only in a few places. The measured calliper was expected to have been close to gauge in size; that the final diameter of the hole is irregular is probably due to the method of drilling (Nielsen et al. 1984). In the lower section drilled in 1996 with a different technique, the calliper is much closer to the bit size within cores (e.g. flow units 83, 86). The hole is narrowest in massive basalt and is usually wider in flow crusts and basal zones and is usually widest of all in sediment. In a few places, the largest diameter is found in porous crust rather than in overlying sediment, possibly indicating that the sediment is more compact or less friable than the lava crust. Where the sediment beds are closely spaced, they do not seem to affect the condition of the hole, suggesting that the presence of nearby basalt stabilises the hole and that the sediment beds are rather competent (Enclosure 1). In places, the massive cores of the flows show minor deviations from stable hole condition that might indicate that the core is fractured or not as massive as presumed (e.g. flow units 42, 46 and 58).

\section{P-, S- and Stonely-wave transit time}

The log curves in Enclosure 1 have been plotted at the same scale but using different intersects, so that $\mathrm{S}$-transit times are within the range $50-170 \mu s e c / f t$ and P-transit times within $10-130 \mu \mathrm{sec} / \mathrm{ft}$. Plotting the curves in this way ensures that they plot on top of one another in massive cores where the hole is at or close to gauge as inferred from the combined interpretation of P-, S- and Stonely transit time, RHOB and NPHI in combination. The steady relationship between the two transit times probably indicates that the physical properties of the cores are fairly stable with a P- to $S$-wave velocity ratio of 1.31 .

Both P-and S-wave transit time logs show a cyclic pattern (Enclosure 1). The sediment beds are characterised by the highest transit time (70-100 $\mu \mathrm{sec} / \mathrm{ft}$ sonic-P) followed by porous crusts and massive cores. Maximum separation of the curves is a strong indicator of sediments, and intermediate separation is considered to represent crust. The velocity gradient in the upper part of flow units $24,26,28,40,41$ and 42 seems to be independent of the thickness of the flow. Transit times within the core units seem to be independent of the thickness of the flow (e.g. flow units 21, 29, 52, 59 and 79) (Fig. 1).

The Stonely-wave transit time is a part of the full-wave sonic survey. Attenuation of the Stonely-waves occurs where fractures are open and may also be caused by changes in permeability. Such attenuation will be more marked in hard formations where the acoustic contrast is greatest between the formation and mud-filled voids (Rider 1996). The cyclic pattern outlined by the P-and S-wave transit time logs is also shown on the Stonely-wave curve, and the smallest amount of oscillation of the curve occurs in the dolerite dykes and in the core of the flow units (Enclosure 1).

\section{Density-porosity}

The bulk density and NPHI porosity curves (measured in limestone porosity units) also show a cyclic nature. The 


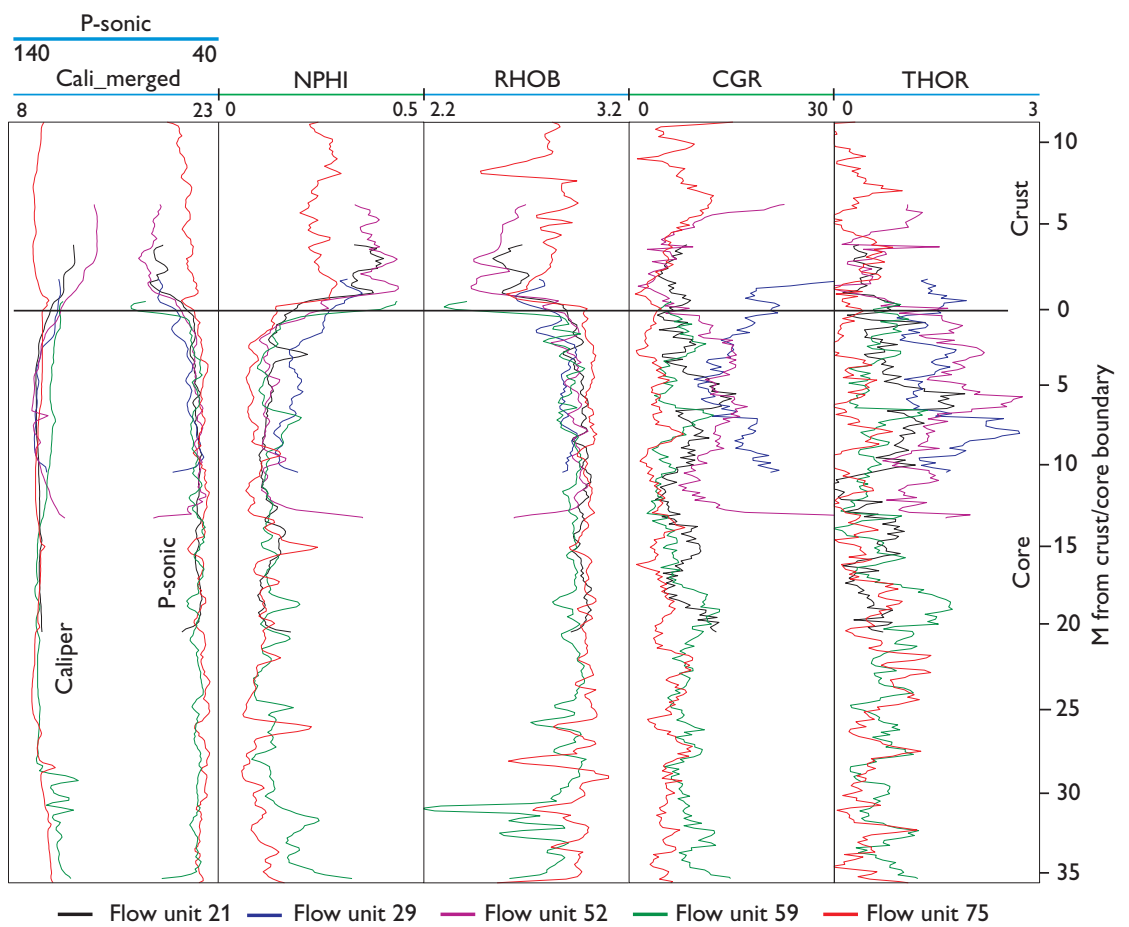

Fig. 1. Variation with depth in five selected flow units. The bimodal behaviour within the flow units is found in the logs representing physical properties but not in the geochemical logs. Variations with depth in the core are most pronounced for the NPHI porosity and RHOB density as compared to the Psonic transit time and calliper. The Psonic transit time appears rather constant. The CGR gamma-ray and thorium curves show the large variations present between different flow units. highest 'porosity' and lowest density values are recorded within the sediments, intermediate values in lava crusts and lowest 'porosity' and highest density values in the lava cores (Enclosure 1). The curves have been plotted at comparable scales, which have been chosen so that they overlap within a typical massive basalt flow, which has been ascribed a density of $2.85-3.00 \mathrm{~g} / \mathrm{cm}^{3}$ and a porosity (NPHI) of $0.1-0.15$. Plotted in this way, a positive separation (where the porosity curve is located to the left of the density curve) is diagnostic of sediment or lava crust whereas no separation of the curves is diagnostic of lava core. Negative separations occur within lava cores that have a lower than average porosity.

\section{Resistivity logs}

The shallow (lls) and deep (lld) resistivity curves were obtained during the first drilling operations in the Lopra-1 well. The log pattern shows a cyclic behaviour comparable to the other logs representing physical properties, reflecting the separation of flow units into crust, core and basal zones. The resistivity values are highest in the core of the flow units where the lld-log reads higher than the lls-log, showing an increase in resistivity away from the hole and into the formation. That could be due to either the formation water being fresher than the mud water and/or that the basalt becomes more massive away from the well. The values in the flow unit crusts are lower than those in the cores, and the separation between the curves is small. The composite flows have a behaviour similar to that of the crust. Sediments have lowest values but the lld-values are still larger than those of the lls-log. Dolerite dykes have the largest values of resistivity, and a large separation of the logs is found.

\section{Geochemical logs}

Five geochemical logs are presented: SGR and CGR gamma ray, potassium, thorium and uranium (Enclosure 1). Basalt that contains both consistently high and consistently low amounts of radioactive material is seen. The shifts from high to low radioactive basalt are remarkably abrupt, and there seems to be no gradual changes, especially for thorium, indicating that thorium represents the original magma (e.g. flow units $7-8,12-13,22-23,23-24,30$ 31, 31-32, 46-47, 55-56, Enclosure 1). In general terms, high thorium values are associated with high potassium and thus high CGR gamma ray, as well as high uranium values. There is a close relationship between the CGR gamma ray and potassium spikes and a less pronounced one between CGR gamma ray and uranium spikes. Sediment is characterised by high localised potassium spikes, often recognised in the CGR gamma ray, that correlate to anomalies in the physical properties logs. In some flow unit 
crusts, a decrease in potassium values with depth was found.

\section{Lithofacies analysis}

The cyclicity of the wire-line log curves has been used to distinguish a number of lithological units including (1) sedimentary layers, (2) flow units of simple type composed of crust, core and basal zone, (3) groups of thin flow units presumably defining composite flows in the sense of Walker (1991), (4) dolerite dykes.

Fifty-two units have been interpreted to be sedimentary beds, identified from a combined interpretation of the potassium, SGR and CGR gamma ray, sonic P-, S- and Stonely-waves, NPHI porosity, RHOB density, calliper and resistivity logs (Enclosure 1). The sediment layers are recognised by gamma ray and potassium spikes relative to the overlying core (and basal zone) and the underlying crust. The gamma ray spike has to be larger than 25 GAPI and be localised within a short thickness interval less than $3.0 \mathrm{~m}$ (98\% of the sediment layers; Fig. 2) and the pronounced potassium spike must contain more than $1 \% \mathrm{~K}$. The uranium values are often high too, but are less diagnostic. In addition, the calliper shows a localised maximum deviation from the bit size, the sonic and NPHI logs record high values whereas the density is low. The thicknesses of the sedimentary layers are generally small, and most of the bed thicknesses fall within the intervals 1.0 $1.5 \mathrm{~m} \mathrm{(38 \% )}$ and $0.5-1.0 \mathrm{~m}(25 \%)$ (Fig. 2). The total thickness of sediments is estimated to be $75.8 \mathrm{~m}$ as compared to $40 \pm 4 \mathrm{~m}$ reported by Nielsen et al. (1984). Within

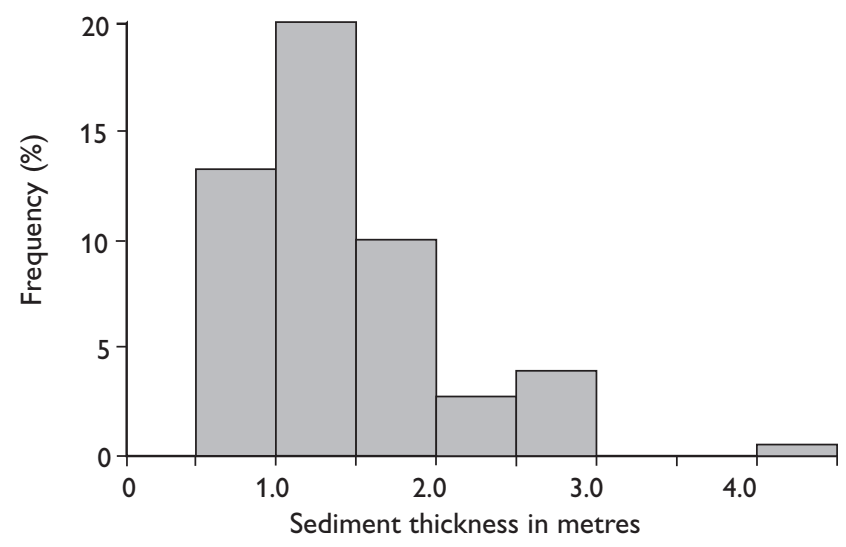

Fig. 2. Frequency diagram illustrating the distribution of sediment thicknesses interpreted in the present study. The sediment layers have been grouped into $0.5 \mathrm{~m}$ thickness intervals. the depth intervals displayed in Enclosure 1, the NPHIporosity and density curves often show a large negative separation. The NPHI-porosity index is large, but the NPHI-porosity often shows a higher value within the crustal part of the underlying flow unit. The density value is low, and generally the lowest value is found in the sediments rather than in the uppermost part of the underlying flow unit (e.g. flow units 12, 20, 29 and 61, Enclosure 1). There are, however, examples where the density values are lower within flow units than within sediments. Thus porosity and density alone are not diagnostic of sediment beds. The P-, S- and Stonely-wave transit times are high within small depth intervals. The shifted transit time curves of the $\mathrm{P}$ - and $\mathrm{S}$-waves show large negative separation, but the values are not diagnostic enough to separate sediment layers from the porous crust of the lava flow. The resistivity values are extremely low. Hald \& Waagstein (1984) and Waagstein et al. (1982) recognised a total of 36 sedimentary beds from analysis of cuttings sampled every $2 \mathrm{~m}$ and, among these, 32 are located below the casing of the well and thus within the 1996 log runs. It has been possible to establish a correlation between the sediment layers interpreted from cuttings and the 1996 $\log$ curves (Enclosure 1), and 27 out of the 32 sedimentary beds can be confirmed by the criteria put forward here. Thus 22 additional sedimentary layers have been identified within the shallower part of the Lopra-1 well.

A total of 87 flow units made up of crust, core and basal zone have been identified using a combination of P-, $S$ - and Stonely-wave transit times, porosity and density values, resistivity values and the calliper log. From the top of each unit downwards to the core, the lava crust is indicated by a general gentle decrease in the sonic transit times combined with a decrease in porosity and increase in density and resistivity (Enclosure 1). Below this crustal zone, the log patterns are replaced by fairly constant low values of transit times and porosity combined with a high value of the density and resistivity, defining the lava core. The core is characterised by the calliper being closely in gauge and low values of the shifted sonic transit time curves, low and small oscillations of the Stonely-transit time curve, no separation of the density and porosity curves, and high values of the resistivity values (Enclosure 1). This fairly uniform behaviour of the log curves is abruptly different near the base of the unit where a pronounced increase in sonic transit time, porosity and calliper values combined with a pronounced decrease in density and resistivity values marks the basal zone. The thickness of the basal zone is generally small, and it has not been possible to differentiate it from the overlying core and the underlying sedimentary layer/crust in a consistent manner, so here the 


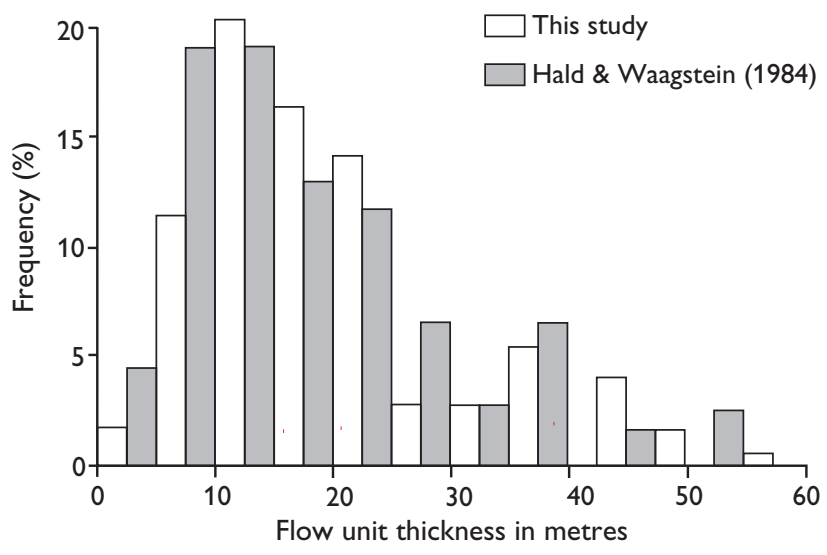

Fig. 3. Frequency diagram illustrating the distribution of flow unit thicknesses interpreted in the present study and in Hald \& Waagstein (1984). The flow units have been grouped into $5 \mathrm{~m}$ intervals.

basal zones have been included in the cores. The behaviour of the log curves representing the basal zone seems independent of whether or not a sediment layer is present beneath it.

The individual flow units are generally reflected in the geochemical logs, primarily in the thorium curve and secondarily in the potassium curve, whereas the SGR, CGR gamma and uranium curves show unsystematic variations (e.g. flow units 6, 29, 39, 44, 51, 52, Enclosure 1). The unsystematic variations do not allow an overall profile to be established as can be done with the logs representing the physical properties. It is therefore concluded that the geochemical behaviour of the flow units is largely related to the original composition of the magma and that different flow fields may be present. The thicknesses of the flow units have been compared to those interpreted by Hald \& Waagstein (1984) and are found typically to be within the range 5-25 $\mathrm{m}$ (of which interval flow units of a thickness of 10-15 m represent 23\%; Fig. 3).

A closer inspection of the curves through the crust and core parts of individual flow units reveals large fluctuations indicating that the physical properties are not constant in either the crust or the core. The nature of the variations in one crust is illustrated in a few examples; in flow unit 18 the porosity increases with depth and the density is rather constant, in flow unit 46 the porosity increases with depth and density decreases, in flow unit 20 the porosity decreases with depth and density increases. Although the porosity and density figures for the crust differ, the relationship between the crust and core seems to be constant apart from those flow units where the crust and core are of similar thickness.

The idealised core as a massive part of the flow unit characterised by constant low values of transit time, low values of porosity and high density and resistivity values is only true for a few flow units, e.g. 20 and 30, whereas different situations are found in e.g. flow units 13, 19, $26,30,36$. Most of the flow units penetrated by the Lopra-1/1A well are characterised by the presence of porosity that may be vesicular zones or fractures within the core, though their regularity seems to indicate that they can be ascribed to vesicular zones. These zones are clearly reflected by the density and porosity curves and deflect the Ssonic transit time curves to a larger degree than they do the P-sonic transit time curves. The vesicular zones within the core are not found at a consistent height above the base or below the top, but most of them seem to display some kind of symmetry. The variation from core to core is exemplified by e.g. flow units 26 and 40 which are most massive at the top and porous in the middle; the core of flow unit 41 is most massive in the upper part, and the vesicular zone is displaced towards the base as compared to the core of flow unit 40 , the core of flow unit 58 is almost symmetrical with a porous zone in the middle, the cores of flow units 31 and 52 become more massive towards the base, and the core of flow unit 59 shows numerous vesicular zones. A minority of cores are massive in the middle and then are less massive both upwards and downwards (e.g. flow units 45 and 48).

Statistical analysis shows that when vesicular zones are present, the core is at least $70 \%$ thicker than the crust, whereas the core and crust are of equal thickness when no vesicular zones are indicated by the logs.

Five flow units $(21,29,52,59$ and 75), representative of flow units of different thickness between 10 and $50 \mathrm{~m}$, have been chosen to illustrate the relationship between flow thickness and mainly velocity. The thicknesses were correlated with the P-wave transit time, the calliper, the NPHI-porosity, density, gamma ray (CGR) and the thorium content logs (Fig. 1). It can be seen that different values of physical properties are recorded in the flow unit depending on whether crust or core is encountered. The flow units vary considerably in their geochemical expression, and the bimodal behaviour of the flow units is not seen. The crust is represented by high values of the calliper, transit time, NPHI-porosity and low values of density. Transit time in the core seems to be fairly constant and therefore independent of the thickness of the core and the flow unit. The variations in values recorded by the calliper seem independent of the thickness of the flow unit (Fig. 1 and Enclosure 1). The relationship between the flow unit thickness and NPHI-porosity and density values of the core seems to suggest that thin flows exhibit high porosity and low density whereas thick flows show 

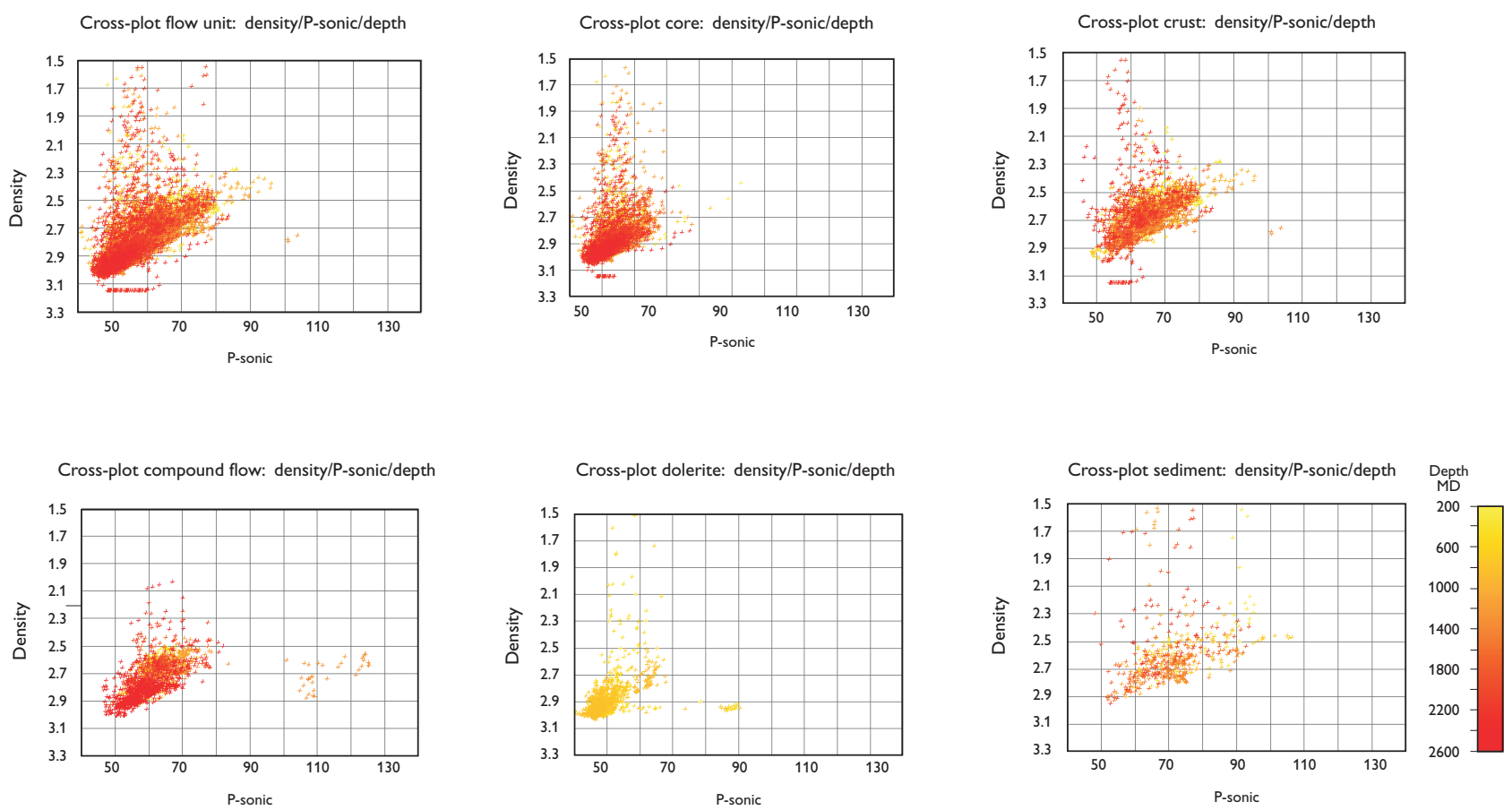

Fig. 4. Cross-plot of inferred lithology: the cross-plots present the statistical behaviour of the flow units, cores, crusts, compound flows, dolerite dykes and sediments plotted for P-sonic transit time versus RHOB density and depth. It is found that the clustering of data is enhanced by plotting the inferred lithology instead of the entire basalt column.
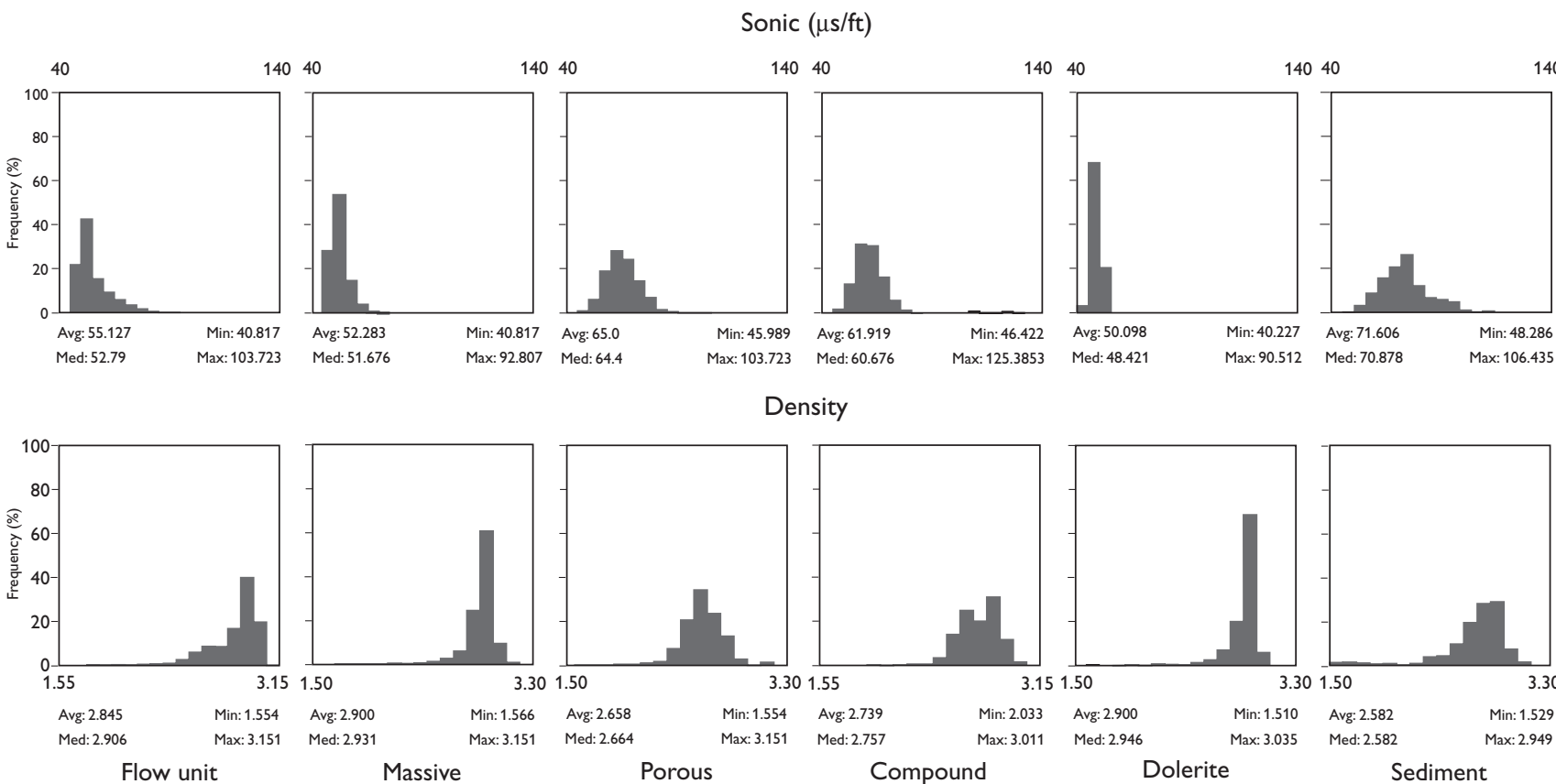

Density

Fig. 5. Histogram and statistical values of the six cross-plots presenting the inferred lithology for P-sonic transit time versus density and depth shown in Fig. 4. The average, median, minimum and maximum values are shown. 
Flow units

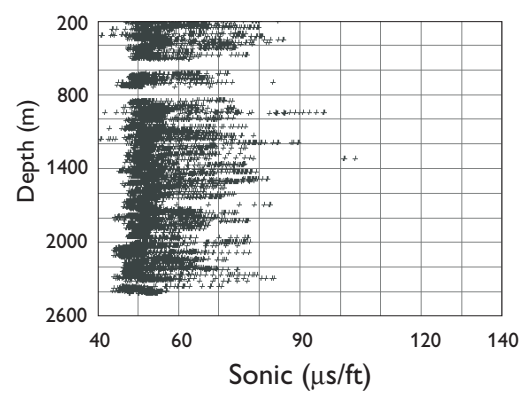

Composite flows

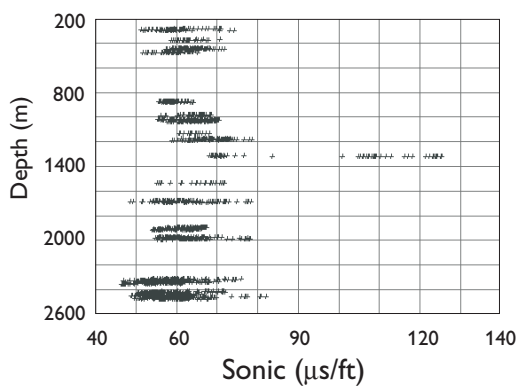

Cores

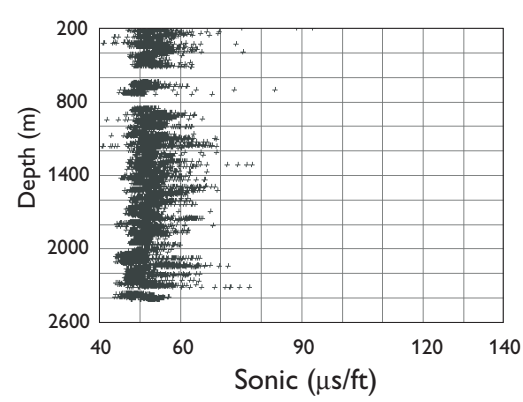

Dolerites

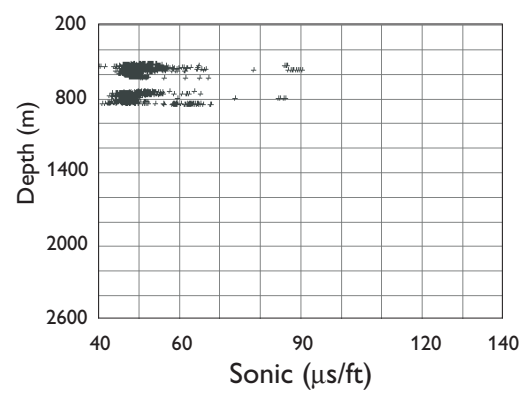

Crusts

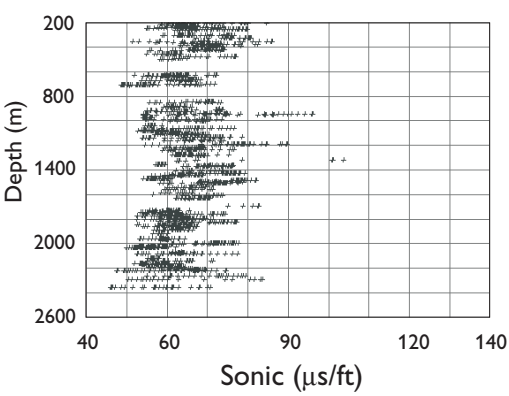

Sediments

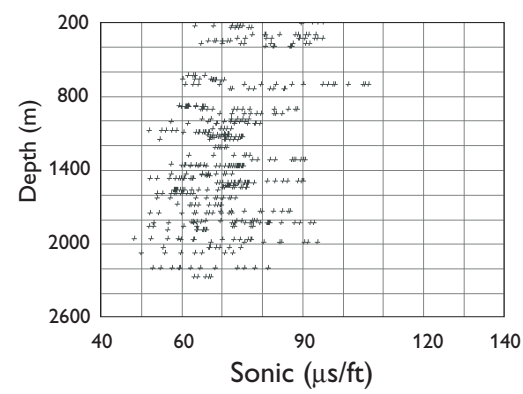

Fig. 6. Cross-plot of P-sonic transit time versus depth for the inferred lithology. The figure shows that the core and sediment lithologies especially show a pronounced trend of decreasing transit time values with depth whereas crust and compound flows are ambiguous. The amount of data representing dolerite dykes is insufficient to describe their relationship with depth. The flow units show a strong increase in transit time with depth but this is due to the core part of the flow unit.

low porosity and high density (Fig. 1) but Enclosure 1 shows that this relation is too simple.

The term 'compound flow' is used for intervals where the cyclicity of the logs representing physical properties suggests strongly that flow units are present, but the individual parts of the flows are poorly defined and log readings do not reach the values normally ascribed to crust or core (Enclosure 1). Eighteen compound flow intervals have been recognised.

Dolerite dykes have previously been encountered at two levels in the Lopra-1 well (Hald \& Waagstein 1984). The dykes are represented by constant values of gamma ray, thorium and potassium lower than found in flow units, rather high density and the lowest values of porosity and transit time combined with the highest values of the resistivity measured in the well (Enclosure 1). The calliper shows that pronounced caving occurred in the upper dyke, but no such caving occurred in the lower one. The dyke intervals were expected to show rather constant values of the log curves representing the physical properties but, as is seen on Enclosure 1, a cyclic appearance of those logs is seen. This cyclic appearance is most obviously seen in the lower dolerite dyke where five symmetric intervals are re- vealed by the RHOB, NPHI, lls and lld logs. This suggests that the lower dolerite dyke consists of five thinner dykes.

\section{Statistics}

The lithological division of the volcanic sequence into flow units (consisting of porous crust and massive core), compound flows, dolerite dykes and sediments makes possible a statistical analysis of the properties of the various lithologies found in the Lopra-1 well. The data obtained from especially the physical properties logs as exemplified by the values of P-, S- and Stonely-wave, porosity, density and resistivity logs (Table 3 ) show a much reduced scatter after being separated into the lithological divisions. A strong correlation, most pronounced for the core and to a lesser extent for the crust and sediment beds, is also found between $\mathrm{P}$ - and $\mathrm{S}$-wave transit times, $\mathrm{P}$ - and $\mathrm{S}$-wave transit times versus density, $\mathrm{P}$ - and $\mathrm{S}$-wave transit times versus porosity, and density versus porosity. Examples are presented in Figs 4 and 5 where six cross-plots with associated histograms and statistical parameters show the benefit 
of dividing the geological column into the suggested lithological units.

The relationship between the physical properties of the lithological units and depth has been examined and a correlation is observed. The degree of correlation is strongest for the flow units (due to the core values), core, sediment/ tuff layers, dolerite dykes and to a lesser extent for crust and compound flows. P-sonic transit time curves are illustrated versus depth for the different lithologies as an example (Fig. 6). There it is seen that especially the sonic transit time increases with depth for the flow units and a first order regression line has been estimated as $\mathrm{P}$-sonic $=$ $58.1370-0.0022 \times$ depth measured in metres or P-sonic $=$ 58.0934-0.0007 $\times$ depth when depth is measured in feet. Likewise a first order regression line estimated for the cores is $\mathrm{P}$-sonic $=54.0165-0.0012 \times$ depth in metres and $\mathrm{P}$-sonic $=54.7769-0.0011 \times$ depth for depths measured in feet. This observation is in accordance with general findings made by Kern \& Richter (1979).

The sediment/tuff layers also show a significant correlation with depth and in general terms the crust does too, whereas the compound flows show no systematic variation. A depth relation for dolerite dykes is not justified because of their limited numbers.

The potassium and CGR gamma ray logs show a strong response to the sediment beds, but there is otherwise no correlation between the geochemical logs and the individual flow units. This probably indicates that the geochemical values are related to the original composition of the flow units, which varies strongly, suggesting that one magma type may represent more than one flow unit. This can be illustrated by analysing the thorium content in relation to flow units and compound flows as defined by the petrophysical logs. The intervals covering the dolerite dykes are not included in this part of the study as they are repor-

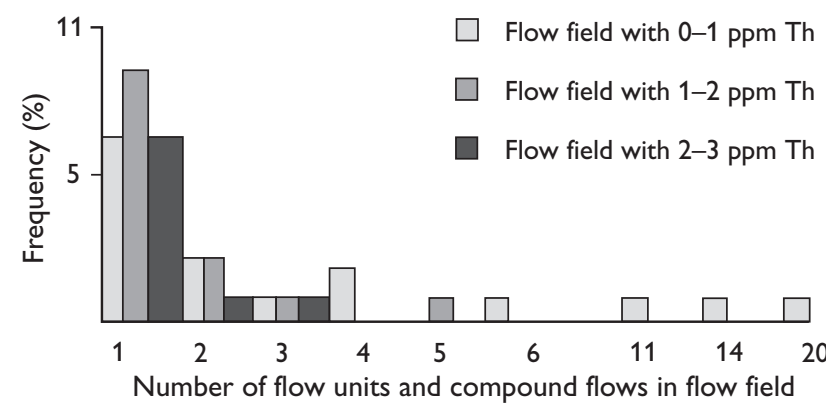

Fig. 7. Frequency diagram illustrating the distribution of the number of flow units or compound flows versus thorium content included in the inferred flow fields. The flow units and compound flows have been grouped into three depending on their thorium content. ted to be later intrusions (Hald \& Waagstein 1984). The thorium log data have been block averaged into three groups according to their thorium content (group 1 consisting of 72 flow and compound flow units with a thorium content of 0.0-1.0 ppm; group 2 containing 21 flow and compound flow units with 1.0-2.0 ppm Th; group 3 with 11 flow and compound flow units representing a content of 2.0-3.0 ppm Th). This results in 36 groups, tentatively interpreted as flow fields (Enclosure 1). Some flow fields are constructed of a number of flows and compound flow units, but $57 \%$ of the flow fields constitute one flow or compound flow unit (Fig. 7). The individual flow fields are separated by sediment/tuff layers in $70 \%$ of cases. Since this study is an analysis of the basalt column based primarily on a lithological division from petrophysical logs, further statistical treatment of the geochemical logs is outside its scope and probably should be done by dividing the lava flows into those with high, medium and low radioactivity.

\section{Discussion}

The flood basalt pile in the interval 200-2486 m depth in the Lopra-1 well has been divided into lithological units based on the wire-line logging (Enclosure 1). Eighty-six flow units consisting of porous crust and massive core (including basal zones), 18 compound flows and two dolerite dykes have been recognised using petrophysical logs (transit time of P-, S- and Stonely-waves, NPHI-porosity, density, resistivity and calliper). Fifty-two sedimentary/tuff layers have been identified mainly by potassium, CGS and SGR gamma logs supplemented by the petrophysical logs. Thirty-seven flow fields have been suggested based on the thorium log in combination with the petrophysical logs.

The flow units have been subdivided into three parts on criteria proposed by various workers based on field evidence or wire-line logs from basalt covered regions (e.g. Planke 1994; Planke \& Flovenz 1996; Waagstein 1999). The Lopra-1 results reveal that overall the crust, core and basal zones are similar to other basalt covered areas reported using wire-line log studies, but there are some differences. To describe the crusts as showing a downward increase in density and resistivity, a decrease in porosity and $\mathrm{P}$ - and $\mathrm{S}$-wave transit times is too simple. The downward increase in density values is commonly replaced by zones of decreasing values, probably reflecting the presence of vesicular or fractured zones. Likewise the previously reported behaviour of the core as being rather uniform although most massive in its middle part (e.g. Planke 1994) is far from true for the flows of the Lopra-1 well. 
Two types of core are commonly present, one type with a 'massive' central part where the logs indicate that only the central part is truly massive. This type, which represents $12 \%$ of the flow units, is generally thin, and the crust is of the same thickness as the core. The other type is characterised by varying numbers of zones of high porosity/low density whose relative depth within the core also varies. In these flow units the thickness of the core is at least $70 \%$ of the total thickness of the flow unit, and the flow units themselves are of different thicknesses. This zonation is interpreted as vesicular or perhaps occasionally fractured zones. The presence of vesicular zones has been reported by McMillan et al. (1987) and Walker (1989). Walker (1989) described the vesicular zonation from spongy pahoehoe lava in Hawaii and mentioned that aa-type lava can also contain vesicular zones. This raises the question whether cores of pahoehoe lavas can be distinguished from those of aa-type lava. Most papers distinguish aa from pahoehoe using surface morphology and perhaps the vertical thickness of the basal zone (Waagstein 1999). Unfortunately surface morphology is not revealed by the present logging suite, and the vertical thicknesses of the basal zone are too small to be treated on their own in the present study. However, Hald \& Waagstein (1984) reported that the majority of basalt from the shallower part of the Lopra-1 well was aa-type lava and that pahoehoe lava in the field seems to have a similar crust and core relationship. It is therefore tentatively suggested that flow units with vesicles may represent aa-type flows, and that the flow units where the crust and core are of the same thickness and the core is massive are pahoehoe type. However only a few studies have dealt with the question of how a flow unit is formed in relation to its distribution of vesicles and cooling history based on cross-sections.

The present study has identified 86 flow units and 18 compound flows compared with the 87 reported by Waagstein et al. (1982) and Hald \& Waagstein (1984). Flow thicknesses of 10-15 $\mathrm{m}(23 \%)$ are most common followed by thicknesses of 15-20 m (18\%) (Fig. 3). Thus the flow unit thicknesses reported here are slightly higher than those of Hald \& Waagstein (1984).

Five flow units of different thickness - tentatively interpreted as aa-type-were chosen by using the transit time of the P-wave, calliper, NPHI-porosity, density, thorium and gamma ray (CGR) logs to analyse the thickness of the flow units (Fig. 1). The petrophysical logs show clearly that different values are ascribed to the crust and core. The expected overall trend of the flow unit in relation to the petrophysical logs is valid. The P-wave transit time in the core is rather constant and not dependent on the thickness of the core and thus of the flow unit. In contrast to the transit time, the NPHI-porosity and density varies, and in the flow units chosen the density seems to increase and the porosity decrease with thickness of the core and thus of the flow unit. That the transit time is independent of the thickness of the core and thus of the flow unit is somewhat different from the results presented by Planke (1994) from a seaward dipping reflector sequence. The behaviour of the radioactive gamma ray and potassium logs in Lopra-1 also differs as they do not show the cyclicity found in the seaward dipping reflectors studied by Planke (1994). Whether this indicates different depositional settings, lava types, magma type, weathering conditions or the fact that fresh water is encountered in the Lopra-1 well is uncertain.

Eighteen compound flows, characterised by similar values of the logs reflecting the physical properties as the crust, have been interpreted. However a cyclic behaviour similar to that in the flow units can be recognised within the compound flows although the values of the P- and Swave transit time, density, porosity and resistivity are lower than in the flow units. It is suggested that the compound flows represent a number of thin flows or the toes of flow units.

Two dolerite dykes were encountered and are characterised by the lowest values of SGR and CGR gamma ray, $\mathrm{P}$ - and $\mathrm{S}$-wave transit time and porosity combined with the highest level of resistivity, high values of density and a constant level of the Stonely-wave transit time curve. The sonic $\mathrm{P}$ - and S-transit time logs and the density, porosity and resistivity curves show a cyclic behaviour resembling the pattern of a flow unit, and it is speculated that the dyke intervals represent a group of thinner dykes.

Fifty-two sedimentary layers have been detected by the combination of potassium, CGR and SGR gamma log, transit time logs of P-, S- and Stonely-waves, NPHI-porosity, density, resistivity and calliper logs. The sediments have been identified on the basis of a locally high spike of the potassium log value in combination with a gamma ray spike larger than $25 \mathrm{GAPI}$, high values of transit time of P-, S- and Stonely-waves, high values of the NPHIporosity and low values of the density and resistivity. The number of sedimentary layers is greater than reported by Hald \& Waagstein (1984) and Nielsen et al. (1984) who reported 27 sediment layers based on the combination of cuttings and geophysical logs acquired in 1981. Of the 27 sediment layers identified by Hald \& Waagstein (1984), the recently acquired geophysical logs used in the present study have confirmed 22 of them.

The sedimentary layers are thought to have formed during periods of quiescent volcanism. In that case, at least 51 periods of quiescence occurred in the interval from 
184 to $2484 \mathrm{~m}$ depth in the Lopra area. Mostly a single flow unit was extruded between each pause, but up to eight flows are found within one interval. The enlarged number of sediment layers indicates that the time intervals between eruptions taking place were shorter than previously thought and thus the extrusion rate of basalt was faster than previously assumed. The amount of basalt produced between the periods of quiescence, measured by the thickness of the flow unit, differs markedly at different depths in the Lopra-1 well. This may indicate that the thickness of basalt produced by a single eruption differed, but to confirm this the location and extension of each eruption needs to be known. The geochemical logs, especially the thorium log, show numerous fluctuations indicating the presence of some highly radioactive basalt flows, similar to those reported in the Deccan Trap area by Buckley \& Oliver (1990). To try to systematise these fluctuations three intervals have been defined $(0-1 \mathrm{ppm}, 1-2$ ppm and 2-3 ppm), and the column was subdivided at the same time into smaller units that appear to correlate with the flow units and sedimentary beds, and on this basis it is suggested that a minimum of 36 units exists. This suggests that 36 different compositions of magma have been present during the time represented by the Lopra- 1 well, and tentatively it is suggested that a minimum of 36 flow fields exists.

Table 2 lists results of other studies of subaerially extruded basalts whereas Table 3 contains the statistical values of the Lopra-1 well wire-line log data from this study. The Lopra-1 results, which are more detailed due to the subdivision into the suggested lithology units, the large thickness of basalt and the extensive logging suite, are in overall agreement with the range of results obtained from the literature survey. Some scattering in measured values exists; however, the amount of data is not sufficient to conclude whether it is the primary volcanic setting or postdepositional processes that are responsible for these differences.

At a depth of approximately $2417 \mathrm{~m}$, the cyclic nature of the wire-line log curves representing the physical properties of the basalt terminates abruptly, and an increase in transit times and porosity combined with a decrease in density signal a transition into the non-subaerially extruded basalt sequence below this level. The transition generates a negative seismic reflection from this level. It is concluded that the negative reflection interpreted from the VSP by Kiørboe \& Pedersen (1995) corresponds to the base of the subaerially extruded basalt. The total known thickness of the flood basalt on the Faroe Islands can therefore be increased by $250 \mathrm{~m}$.

\section{Conclusions}

The study shows that it is possible to use wire-line logging combined with results from work carried out in flood basalt regions in other parts of the world to divide the subaerial plateau basalts drilled in the Lopra-1 well into a number of lithological units. Fifty-two sedimentary layers have been identified using geochemical logs supplemented by the logs representing physical properties. Eighty-six basaltic flow units (consisting of a vesicular crust, a massive or partly vesicular core and a thin basal zone), 18 compound flows and two dolerite dykes have been identified using the logs representing physical properties supplemented by the geochemical logs. Tentative aa and pahoehoe lava types are suggested, among which the aa lava is the most common. The geochemical logs appear to respond to the composition of the magma rather than reflecting individual flow units, and it is suggested that the Lopra- 1 well penetrated a minimum of 36 flow fields. The present subdivision of the lithology is strongly supported by statistical analysis of the logged physical parameters and shows that a pronounced reduction in data scatter is obtained when the basalts are studied as individual units. Thus the study presents consistent and detailed information about the lower series of the Faroe plateau basalts that has led both to new results and results in greater detail than was previous known, which is of benefit in geophysical and geological studies of basalt and pre-basalt geology.

\section{Acknowledgements}

Thanks are due to the Lopra consortium and the Geological Survey of Denmark and Greenland for access to the wire-line log data. Thanks are due to Dr. H. Delius for assistance in correcting the resistivity logs. Thanks are due the reviewers Professor Dr. D. Goldberg and Professor Dr. P.K. Harvey for valuable and constructive suggestions that have improved the content. J.A. Chalmers is thanked for valuable suggestions that improved the language. Landmark is acknowledged for the University Grant issued to the Geological Institute, University of Copenhagen.

\section{References}

Berlitz, R. et al. 1988: Log interpretation in igneous and metamorphic rocks with five case studies. Technical Review 36, 30-47.

Berthelsen, O., Noe-Nygaard, A. \& Rasmussen, J. (eds) 1984: The deep drilling project 1980-1981 in the Faeroe Islands. Annales 
Societatis Scientiarum Faeroensis, Supplementum IX, 158 pp. Tórshavn: Føroya Fróðskaparfelag.

Buckley, D.K. \& Oliver, D. 1990: Geophysical logging of water exploration boreholes in the Deccan Traps, central India. In: Hurst, A., Lovell, M.A \& Morton, A.C. (eds): Geological application of wire-line logs. Geological Society Special Publication (London) 48, 153-161.

Cashman, K.V. \& Kauahikaua, J.P. 1997: Reevaluation of vesicle distribution in basaltic lava flows. Geology 25, 419-422.

Christensen, N. 1996: Poisson's ratio and crustal seismology. Journal of Geophysical Research 101(B2), 3139-3156.

Goldberg, D.S., Reynolds, D.J., Williams, C.F., Witte, W.K., Olsen, P.E. \& Kent, D.V. 1994: Well logging results from the Newark Rift Basin Coring Project. Scientific Drilling 4, 267-279.

Hald, N. \& Waagstein, R. 1984: Lithology and chemistry of a 2 $\mathrm{km}$-sequence of Lower Tertiary tholeiitic lavas drilled on $\mathrm{Su}-$ ðuroy, Faeroe Islands (Lopra-1). In: Berthelsen, O., Noe-Nygaard, A. \& Rasmussen, J. (eds): The deep drilling project 19801981 in the Faeroe Islands. Annales Societatis Scientiarum Faeroensis, Supplementum IX, 15-38. Tórshavn: Føroya Fróðskaparfelag.

Kern, H. \& Richter, A. 1979: Compressional and shear wave velocities at high temperature and confining pressure in basalts from the Faeroe Islands. Tectonophysics 54, 231-252.

Kiørboe, L.V. \& Pedersen, S.A. 1995: VSP seismic experiment in the Faeroes. In: Scrutton, R.A. et al. (eds): The tectonics, sedimentation and palaeoceanography of the North Atlantic region. Geological Society Special Publication (London) 90, 111-123.

Lund, J. 1983: Biostratigraphy of interbasaltic coals from the Faeroe Islands. In: Bott, M.H.P. et al. (eds): Structure and development of the Greenland-Scotland Ridge. NATO Conference Series IV: Marine Science, 417-423. New York/London: Plenum Press.

McMillan, K., Randal, C.W. \& Long P.E. 1987: Two-stage vesiculation in the Cohassett flow of the Grande Ronde Basalt, southcentral Washington. Geology 15, 809-812.

Nielsen, P.H., Stefánsson, V. \& Tulinius, H. 1984: Geophysical logs from Lopra-1 and Vestmanna-1. In: Berthelsen, O., NoeNygaard, A. \& Rasmussen, J. (eds): The deep drilling project 1980-1981 in the Faeroe Islands. Annales Societatis Scientiarum Faeroensis, Supplementum IX, 115-135. Tórshavn: Føroya Fróðskaparfelag.

Planke, S. 1994: Geophysical response of flood basalts from analysis of wire-line logs. Ocean Drilling Program Site 642, Vøring volcanic margin. Journal of Geophysical Research 99(B5), 92799296.
Planke, S. \& Flovenz, O.G. 1996: Seismic properties of flood basalt (extended abstract), 6 pp. Geophysics for lithology predictions. Kristiansand: Norwegian Petroleum Society.

Rasmussen, J. \& Noe-Nygaard, A. 1969: Beskrivelse til geologisk kort over Færøerne i målestok 1:50 000. Danmarks Geologiske Undersøgelse 1. Række 24, 370 pp. + map vol. (with summaries in Faeroese and English).

Rasmussen, J. \& Noe-Nygaard, A. 1970: Geology of the Faeroe Islands (pre-Quaternary). Danmarks Geologiske Undersøgelse 1. Række 25, 142 pp.

Rasmussen, J. \& Noe-Nygaard, A. 1990: The origin of the Faeroe islands in text, pictures and on maps, 64 pp., 6 maps at 1:50 000. Copenhagen: Geological Survey of Denmark (also text in Faeroese and Danish).

Rider, M. 1996: The geological interpretation of well logs, 2nd edition, 256 pp. Houston, Texas: Gulf Publishing.

Sanyal, S.K., Juprasert, S. \& Jubasche, M. 1980: An evaluation of a rhyolite-basalt-volcanic ash sequence from well logs. Log Analyst 21, 3-9.

Self, S., Thordarson, T. \& Keszthelyi, L. 1997: Emplacement of continental flood basalt lava flows. In: Mahonney, J.J. \& Coffin, M.F (eds): Large igneous provinces: continental, oceanic and planetary flood volcanism. American Geophysical Union Geophysical Monograph 100, 381-410.

Singh, S.C. 1996: Delineation of basaltic lava flows through geophysical logging. Gondwana Geological Magazine Supplemented 2, 539 only.

Thordarson, T. \& Self, S. 1998: The Roza Member, Columbia River Basalt Group. A gigantic pahoehoe lava flow field formed by endogenous processes? Journal of Geophysical Research 103, 411445.

Waagstein, R. 1999: A geological field guide to the Palaeogene flood basalts of Suðuroy, Faroe Islands. Danmarks og Grønlands Geologiske Undersøgelse Rapport 1998/130, 46 pp.

Waagstein, R., Nielsen, P.H., Fine, S. \& Hald, N. 1982: Lopra well no. 1, Suðuroy, Faroe Islands. Geological well completion report, 40 pp. Unpublished report, Geological Survey of Denmark, Copenhagen.

Walker, G.P.L. 1989: Spongey pahoehoe in Hawaii: a study of vesicle-distribution patterns in basalt and their significance. Bulletin of Volcanology 51, 199-209.

Walker, G.P.L. 1991: Structure, origin by injection of lava under surface crust, of tumuli, 'lava rises', 'lava-rise pits', and 'lavainflation clefts' in Hawaii. Bulletin of Volcanology 53, 546-558. 